\title{
HTML Browser
}

National Cancer Institute

\section{Source}

National Cancer Institute. HTML Browser. NCI Thesaurus. Code C80012.

A program used to view an HTML document. 